THURSDAY, NOVEMBER 20, 1873

\section{THE ARCTIC EXPEDITION OF 1874}

$7 \mathrm{HE}$ prospect of the Government being convinced of the propriety of despatching an Arctic Expedition, really seems to be brightening. We expressed some apprehension, when the Royal Geographical Society addressed the late Chancellor of the Exchequer on the subject last year, that sufficient pains were not taken to have all branches of Science represented in the Deputation, and that, consequently, the importance of the results of Arctic Research had not been completely explained. There is no cause for any such doubt on the present occasion. The matter has been most carefully and maturely considered by a joint committee appointed by the Councils of the Royal and the Royal Geographical Societies, and consisting of representatives of various departments of Science as well as of the most eminent Arctic authorities.

A memorandum has been drawn up, and submitted to the Council of the Royal Society, in which the scientific results to be obtained from the examination of the unknown area round the North Pole are set forth; the different sections having been prepared by men who are in the first rank as authorities in their particular departments of study-namely, geography, hydrography, geodesy, physics, meteorology, geology, botany, zoology, and anthropology. The memorandum also includes a carefully prepared statement, drawn up by distinguished Arctic authorities of the practical aspects of the question, the composition of such an expedition, the precautions that should be taken, and the best route.

The Royal Society is a body which, from its high position and from its strong sense of responsibility, never takes action without very careful and mature previous consideration. When this body once adopts a course on any question, the public can always feel satisfied that it has first received the closest attention, in all its bearings, from men of the highest attainments. The memorandum of the Committee has been before the Council, and we are able to announce that the value of the scientific results to be derived from Arctic exploration has been recognised, and that the Royal Society is prepared to represent to the Government the desirability of undertaking the discovery of the unknown region.

With the object of inducing the Government to undertake a North Polar Expedition, the Council of the Royal Society has appointed a deputation to represent their views, consisting of Dr. Hooker, the President-elect, Prof. Huxley, Prof. Allman, Mr. Prestwich, Mr. Busk, Mr. Sclater, and General Strachey.

The British Association has also appointed a Committee with the same object.

The Royal Geographical Society will be represented by its President, Sir Bartle Frere, Sir Henry Rawlinson, the veteran Arctic explorer, Sir George Back, and Admirals Collinson, Ommanney, and Sherard Osborn.

The Dundee Chamber of Commerce is also deeply impressed with the practical importance of discovery in the unknown area, and has drawn up a memorial to be presented to the Prime Minister, through the member, Sir John Ogilvy. Dundee is not only the principal VOL, IX, -NO. 212 whaling port of Great Britain, but is also the centre of a great and thriving industry, namely, the manufacture of jute, the growth of which employs millions of ryots in Bengal. Now, in the process of preparing the jute fibre, the use of animal oil is essential, so that the business of chasing whales and narwhals in the Arctic seas is of the utmost importance to the cultivators of the Gangetic delta. One industry supports the other, and India, as well as Great Britain, has an interest in Arctic discovery. The Chamber of Commerce, considering the vast interests at stake, holds it to be most important that the unknown polar region should be explored, in order that a more complete knowledge may be acquired of the haunts, migrations, numbers, and habits of the various oilyielding animals. The Chamber also feels the advantages derived from Arctic expeditions by the best among the experienced mates and harpooners who obtain employment, and indirectly by the whole seafaring population of the west coast of Scotland. Nor are the bold seamen and enterprising manufacturers of the northern ports, any more than the naval officers and men of science, indifferent to the old renown of their country, and to the immense advantages which are derived from voyages of discovery.

The events of the last year have strengthened the arguments in favour of an Arctic Expedition. We believe that the despatch of a naval officer to Baffin's Bay last spring was due to the forethought of Admiral Sherard Osborn. The choice was undoubtedly a fortunate one, for Captain Markham entered heart and soul into the spirit of the service on which he was employed. He studied the new system of ice navigation, and of handling powerful steamers in the ice with minute attention. $\mathrm{He}$ had the rescued crew of the Polaris on board for several months, and learned from Dr. Bessels and Mr. Chester all the particulars of their extraordinarily successful voyage. Nothing escaped him, and on his return he submitted a full and most valuable report. Thus the fact that a ship can pass up Smith Sound to $82^{\circ} 16^{\prime} \mathrm{N}$. without check of any description, unknown before, is now established, as well as the constant movement and drift of the ice in the strait leading to the unknown region. The revolution in ice navigation, caused by the use of powerful steamers, is also more fully understood and appreciated through the report of Captain Markham.

The deputation which is about to seek an interview with Mr. Gladstone and Mr. Goschen, is thus strengthened with fresh arguments and with a more exact and complete statement of the objects of Arctic research. It will represent interests which cannot be neglected, and bodies whose individual opinions must needs carry great weight. There will be the Royal Society, the recognised adviser of the Government on all matters relating to Science; the Royal Geographical Society, the British Association, and the Dundee Chamber of Commerce representing the interests of a great industry and of the sea-faring population of Scotland. The navy will also be fully represented, and the leading Arctic authorities will be present, acting in perfect unanimity as regards the route to be taken and the work to be done.

We believe that such a deputation must have considerable influence on the decision of the Government, and that there is every prospect of sanction being given to 
the fitting out of a naval Arctic expedition in I874. Mr. Goschen is, we have reason to think, now conversant with the subject, and, as the Minister whose duty it is to advance and foster the interests of the British navy, it is imposible that he can fail to see the advantages of Arctic service. $\mathrm{He}$ is supported, at the Admiralty, by Sir Alexander Milne, who has ever been friendly to such enterprises, and sensible of the excellent school for nnval men afforded by voyages of discovery; and by Admiral Richards, the hydrographer, whose sound judgment and great Arctic experience render his advice most valuable.

The Prime Minister, with whom the decision will rest, is a statesman who well knows the general, as well as the scientific uses of Arctic enterprise. He formed one of that Ministry which despatched the last scientific expedition to the Arctic Regions; and, as a member of the Select Committee of the House of Commons on Sir John Ross's case, he signed a report expressing his approval of Arctic voyages in the strongest terms-" A public service is rendered to a maritime country, especially in times of peace, by deeds of daring, enterprise, and patient endurance of hardship, which excite the public sympathy and enlist the general feeling in favour of maritime adventure." Such were, and we trust still are, the views of $\mathrm{Mr}$. Gladstone with reference to the general uses of Arctic voyages of discovery. When to these general impressions are added a knowledge of the important scientifie and practical results to be attained, the assurance that there is no undue risk, that the cost will be comparatively slight, and the good both to the navy and to mercantile interests incalculable, we cannot bring ourselves to believe that the decision of Mr. Gladstone will not be favourable to a renewal of Arctic research.

\section{LOCAL SCIENTIFIC SOCIETIES*}

II.

A

LTOGETHER, so far as we have been able to ascertain, + the number of existing local societies $\$$ which have for their main, or only as a part of their object the culture of Science, that were established in the years between $178 \mathrm{r}$ and 1830 , are only 22 . We shall see that the increase since 1830 has been enormous, though the large majority of those established during the last forty-three years are of a much more simple kind, so far as organisation is concerned, than those established during the former period, have to a great extent a different object in view or rather accomplish the intellectual improvement of the members after a different fashion, and are, we think, thoroughly characteristic of the scientifically inquisitive and increasingly intelligent period during which they have been established. Not many "Literary and Philosophical Societies" have been established during the latter period, most of them being professedly devoted to study and research in Science, especially in natural history, in all or one of its branches, and a large majority of them being Field Clubs, as those associations are called, the whole or part of whose programme is to investigate the natural history (including . botany, zoology, and geology) of particular district $s$, in combination sometimes with

* Continued from vol. viii. p. 524 .

$\dagger$ We regret to say that none of the Edinburgh Societies have seen meet to forward us information.

1 We do not include in this article the great London Societies, as the Royal, the Linnean, the Astronomical, \&c. their archæology. Indeed the last forty years might well be designated the era of field clubs.

We have already mentioned the Northumberland, Durham, and Newcastle Natural History Society, established in 1829 , which, although it has done some excellent field club work, was not professedly established for this purpose. There can be no doubt that the first genuine fieldclub was the Berwickshire Naturalists' Club, founded September 21, I83r, though Sir Walter Elliot traces the true origin of field-clubs to an association of students, formed in 1823 at the University of Edinburgh, under the name of the Plinian Society, for the advancement of the "study of natural history, antiquities, and the physical sciences in general." They met weekly in the evening during the session, from November to July, for reading papers and discussions; and also, as the season advanced, made occasional excursions into the neighbouring country. The chief promoters of the scheme were three brothers named Baird, from Berwickshire; but John, the eldest, must be considered the founder. He drew up an elaborate code of laws in eighteen chapters, and, as the first president, made a statement of the proposed plan and objects of the society at their inaugural meeting on the 14th January I823. Among the original members occur the names of James Hardie, J. Grant Malcolmson (both Indian geologists), and Dr. John Coldstream; and, at a later period, those of Charles Darwin * (of Shrewsbury, 1826), John Hutton Balfour (1827), and Hugh Falconer (r828), with others who have since become distinguished in the scientific and literary world. The latest notice of the society is the session of $1829-30$, up to which time the Bairds, although they had left the University, appear as occasional contributors.

No doubt this Edinburgh Association had considerable influence in originating the Berwickshire Club, for two of the Bairds became parish ministers in Berwickshire, and it was they, along with their brother, the late Dr. William Baird, of the British Museum, Dr. Johnstone, Dr. Embleton, and four or five others, who met at Coldingham on the date above given, and drew up the plan of the Berwickshire $\mathrm{Na}$ turalists' Club, "a term," Sir W. Elliot remarks, "now first extended to a scientific body." Its object was declared to be the "investigation of the natural history of Berwickshire and its vicinage ;" in reality its field extends over the whole of Berwickshire, Roxburghshire, and the northeast part of Northumberland, to the limits of the Tyneside Club's district. The rules of the club, as all rules should be, are short, providing that the club should hold no property, require no admission fee, and should meet five times in the year at a place and hour to be communicated to each member by the secretary. Thus the Berwickshire Club is a field-club pure and simple, having, unlike many other similar clubs, no winter meetings for the reading of papers, whatever papers are read being read after dinner on the days when excursions are made. At the first anniversary it numbered 27 members, and in 1870, when Sir Walter Elliot gave his address, there were 249 members on the roll, including a few ladies, and "two corresponding members, the last description having been

* The first paper contributed by him, entitled "On the Ova of the Flustra," in which he announces that he has discovered organs of motion, and, secondly, that the small black body hitherto mistaken for the young of Frucus loreus is in reality the ovim of Pontobdella murcata, exhibits his early habits of minute investigation. 